\title{
Globalization: In Terms of Teachers' Opinion and Metaphorical Perceptions
}

\author{
Semih Çayak ${ }^{1, *} \&$ Menekşe Eskici \\ ${ }^{1}$ Republic of Turkey Ministry of National Education, İstanbul, Turkey \\ ${ }^{2}$ Educational Sciences, Faculty of Arts and Sciences, Kırklareli, Turkey \\ *Correspondence: Republic of Turkey Ministry of National Education, İstanbul, Turkey. E-mail:
} semihcayak@gmail.com

This article was presented as abstract at the 3rd International Conference on Lifelong Education and Leadership for All. ICLEL 2017/September 12-14/Polytechnic Instute of Porto, Porto-Portogual.

Received: April 24, 2018

Accepted: May 15, $2018 \quad$ Online Published: May 27, 2018

doi:10.5430/wje.v8n3p44

URL: https://doi.org/10.5430/wje.v8n3p44

\begin{abstract}
The purpose of this paper is to investigate teachers' opinion and metaphorical perceptions about globalization. In this paper, phenomenology one of the qualitative research type was used. 61 teachers' metaphorical perceptions about globalization were collected and interviewed with 12 teachers about globalization in education. Teachers' metaphorical perceptions about globalization were determined by a space filled question (globalization is similar to...; because ...). A semi-structured interview form has been prepared by the researchers. The opinions of the teachers can be summarized as teachers associate globalization with technology, especially with the internet. In general teachers mentioned that the effects of globalization in education are positive. Further teachers' metaphorical perceptions about globalization summarized as follows; village, market, whirlpool, family, shopping, teapot, neighborhood, technology. Withal teachers' reasons for analogy of the metaphors about globalization are grouped as; globalization as a unifying of differences concept, globalization as a communication and interaction enhancer concept, globalization as a damaging concept and globalization as an indefinite concept.
\end{abstract}

Keywords: globalization, teachers' opinion, metaphorical perceptions

\section{Introduction}

Within the historical process, it is seen that different phenomenons have left its mark on different periods. The globalization phenomenon (Öz-Kılınç, 2009), a key concept describing the increasing in interdependence of today's societies in which no life in any country is not separated entirely from the rest of the world anymore, indicates changes and transformations which are in various fields from information to economy, from culture to politics in a way of the interaction, dependence, merger and integration (Şener, 2014).

The rapid changes in the fields of communication, information and informatics depending upon scientific, technological and economic development, have brought out the concept of globalization by removing the importance of the boundaries between nations (Akdemir, 2004). Globalization which is a concept leaving its mark on 21 st century (Y1lmaz, 2004), is one of the most-debated concepts nowadays especially in the academic and economical circles (Yllmaz \& Horzum, 2005, Kaya, 2009). Globalization, which is used to express the change almost in every field of the world from the economy to politics, social politics to culture (Bozkurt, 2000), can be considered as a characteristic feature of education as well (Kartal, 2007).

The concept, Globalization, from the USA was successfully introduced in the world literature and took part in its place today (Dağl1, 2007). Despite the fact that the concept of globalization (Kürkçü, 2013), whose originators are liberal thinkers such as Muray Rohtbard and David Friedman, is not a common idea, it is a concept symbolizing the change in every area on which it has affected, and whose profound effects are seen especially in information and economy as well as other social fields (Çavuşoğlu, 2007). While Şahin (2011) defines globalization as the spreading of some values and structures to the world scale by transcending over local and national boundaries in terms of economic, political and cultural aspects, Kan (2009) defines globalization as structure which was formed resulting of further confrontations of 
different countries together with the development of communication and transportation possibilities. In furtherance of the other definitions of globalization, Power (2000) states that globalization causes the world to shrink even further.

The globalization that affects people, societies and states as a postmodern dimension of change (Doğan, 2002), in the whole world's single ground axis that it revealed with its different processes and actors, means that the concentration of economic relations, the flow of information easily transcending physical boundaries, the new reference point in the fields of identity and culture, the becoming of global problems into a common problems of all mankind (Ateş, 2007; Holton, 2000). As pointed out by Karaman (2010), while, the process of resemblance of societies to each other in the process of globalization reveals a global culture the differences on the other hand point out to the cultural diversity of societies.

It is possible to define the globalization widely as removing of national borders and integration of free markets by transcending these borders in consequence of movement of money and goods and development of trade and knowledge (Yorgun, 1998). But in essence, it seems that globalization is not a system in which the borders of the country are removed as it is asserted by many people. As a matter of fact, the borders of the country are necessary for the survival of cheap labor repository. However, globalization is far from the concept of nationalism that is defined by boundaries. When global companies go to other countries for cheap labor, jobs are created in these countries, but this leads to unemployment in rich countries. In this respect, it is also a fact that globalization is distorting the international and inland income distribution (Ertuna, 2006).

Globalization, which had not been widely used until the beginning of the 1960s, even though it has a history of over 400 years, were particularly influential in international trade in the 1950s and 1960s (Erdinç, 1999). Another important process behind the phenomenon of globalization is that societies become information societies through developing technology (Guidelines, 2002). Oran (2000) who stated that the globalization process took place in three phases, stated that the first phase began with the discovery of the American continent in 1492, followed by the second phase taking from the 1870 s to the $1890 \mathrm{~s}$ in which the globalization institutionalized, and lastly he stated that it was proceeded to the third phase which began with revealing of the multinational corporations in the 1970s, went on with communication revolution in the 1980s, became popular in the 1990s by means of non-rival of West.

Approaches concerning to globalization in the literature are classified as "extreme globalization supporters", "skeptics" and "transformationalists" by following Held, McGrew, Goldbaltt and Perraton (Bozkurt, 2010; Elçin, 2012). All three groups defined the concept of globalization according to their own, but they did not radically rejected this period that were lived. Because the main difference between these three views stem from their worldviews that they represent rather than from phenomenons (Elçin, 2012; Yalçınkaya, Çılbant \& Yalçınkaya, 2012).

There have been positive and negative effects concerning to globalization as well as positive and negative effects of every change and transformation. The common values of man have begun to emerge, human and his works, culture and civilization have been re-interpreted over again. From this point of view, it was understood that educating only the people from select segment of each country is not the way to go, and there is a need for a quality population who was mass-grown by an education system reaching grassroots level for development. It was also an inevitable ending that common understanding and perception developed among the citizens of the country through the establishment of new and common lifestyles among people and common education policies (Bilhan, 1996; Balay, 2004).

Globalization has a close relationship with education (Çelik \& Gömleksiz, 2000). Because raising creative and innovative people is the main purpose of the information age education. In this respect, it is now necessary to teach the individual how and in what ways he will access to information needed rather than directly transferring information to the individual (Çalık \& Sezgin, 2005). According to Kirkwood (2001), the world's shrinking and becoming a global village has also reflected to the educational process. Therefore, in the process of globalization, education is seen as a process that provides continuously learning, knowing knowledge, being knowledgeable, producing knowledge, living with knowledge, that is, a process that raises the individuals who fulfill the requirements of globalization (Dağll, 2007, Titrek, Güneş, \& Sezen). According to Pike (2000), this must be carried out by planting global values without giving up national education in this globalizing world.

On the other hand, student exchange programs are becoming widespread at almost every level of education nowadays. This situation leads students to think globally by giving them the opportunity to recognize different countries and cultures, to find jobs in different countries or to establish them (Tezcan, 2002). In addition, schools and universities are opening their branch offices in other countries through bilateral agreements, which require distance education. Thus, globalization is creating an international educational market (Çınar, 2009). Levitt (1984) states that one of the key benefits of globalization is that it is allowing low-income groups to be trained for adapting to modern life. 
Raising students who can successfully adapt to the globalizing world is only possible with the teachers who were self-educated about globalization in the education sector. In this case, the education that teachers have from the teaching period to the in-service training needs to be regulated in the context of globalization. At the beginning of the topics to be considered in the regulation of the teachers' education are the opinions and thoughts of the teachers. From this point of view, it was tried to determine the global views and metaphorical perceptions of teachers in this research.

\subsection{Problem Statement}

What are the teachers' opinions and metaphorical perceptions about globalization?

\subsection{Sub-problems (Hypotheses)}

1.What are the teachers' metaphorical perceptions about globalization?

2.What are the teachers' opinions about globalization?

\section{Method}

This section contains information on the design of the research, study group, data collection tools, collection and analysis of data.

\subsection{Method of the Research}

The phenomenology design, one of the qualitative research types, was used in this study in which views of teachers on the concept of globalization and their metaphorical perceptions were investigated, in the study. The data of the research shows a triangulation method feature in terms of being obtained by interviews with teachers and by metaphors collected from teachers. Triangulation is based on careful examination of the data obtained by different methods in order that qualitative researches and their results produce more accurate and valid estimates for a specific structure (Oliver-Hoyo \& Allen, 2006; Yeasmin, \& Rahman, 2012).

\subsection{Population-Sampling}

The data of the research were obtained from the teachers who were working in different branches in the province of Kirklareli in the academic year of 2016-2017. Teachers who participated in the research were selected by easy accessibility method. 61 (39 females, 22 males) teachers' metaphorical perceptions about globalization were collected and interviewed with 12 ( 8 females, 4 males) teachers about globalization in education.

\subsection{Data Collection Tools}

Teachers' metaphorical perceptions about globalization were determined by a space filled question (globalization is similar to...; because ...). Besides a semi-structured interview form has been prepared by the researchers to determine the opinions of teachers about globalization. The form have five questions; "How does globalization affect the class climate?", "What are the advantages of globalization over the educational process?", "What are the disadvantages of globalization on the educational process?", "What should be done for better education in the globalizing world?" and "How does globalization affect your career plans?"

\subsection{Analysis Techniques}

The qualitative data of collected were analyzed through content analysis technique.

\subsection{Reliability and Validity of Data}

Two researchers analyzed the content of the data separately. The two results compare with each other in the light of the formula "Reliability = Consensus / Consensus + Disagreement x 100". Compliance rate between two outcomes was found as .76. It can be said that the analyzes are reliable based on this result (Miles \& Huberman 1994).

\section{Findings}

In this section, the metaphors produced by the teachers for the concept of globalization and the frequencies of these metaphors are given. Later, the categories that were created from these metaphoric images were explained by supported by the quotations produced by the teachers.

\subsection{Metaphor Images and Frequencies Related to the Concept of Globalization}

When the metaphorical images that teachers used in relation to the concept of globalization are examined, a total of 56 valid and 41 different metaphor images were obtained from 61 teachers. Teachers' metaphorical perceptions about globalization summarized as follows; village (4), market (4), whirlpool (3), family (3), shopping (3), teapot (2), 
neighborhood (2), technology (2). Metaphor images that a part from these metaphor images were once preferred. The results Presented in Table 1.

Table 1. Metaphor İmages and Frequencies Related to the Concept of Globalization

\begin{tabular}{llll}
\hline Metaphor İmages & f & Metaphor İmages & f \\
\hline Village & 4 & Human (Live) & 1 \\
Market & 4 & District & 1 \\
Whirlpool & 3 & Communication & 1 \\
Family & 3 & Kinship & 1 \\
Shopping & 3 & Butterfly Effect & 1 \\
Teapot & 2 & Matryoshka & 1 \\
Neighborhood & 2 & Metropol & 1 \\
Technology & 2 & Heterogeneous Fluid & 1 \\
İnternet & 2 & Competition & 1 \\
Mall & 1 & Picture & 1 \\
Peer Bullying & 1 & Industry & 1 \\
Bee & 1 & Book With No Page Number & 1 \\
Military & 1 & Smoking & 1 \\
Fire & 1 & Fog Screen & 1 \\
Swamp & 1 & Supermarket & 1 \\
Knowledge Society & 1 & Process & 1 \\
Damaged Scales & 1 & Blaze & 1 \\
Wheel Gears & 1 & Degeneration & 1 \\
Desert & 1 & Time Travelling & 1 \\
Pit & 1 & Total & 56 \\
Soccer Ball & 1 & &
\end{tabular}

\subsection{Reasons for Metaphorical Similarity to the Concept of Globalization}

Teachers' reasons for analogy of the metaphors about globalization are grouped as; globalization as a unifying of differences concept $(f=21)$, globalization as a communication and interaction enhancer concept $(f=19)$, globalization as a damaging concept $(\mathrm{f}=13)$ and globalization as an indefinite concept $(\mathrm{f}=3)$. The results Presented in Table 2.

Table 2. Reasons for Metaphorical Similarity to the Concept of Globalization

\begin{tabular}{llc}
\hline \multicolumn{1}{c}{ Categories } & \multicolumn{1}{c}{ Metaphor İmages } & f \\
\hline $\begin{array}{l}\text { Globalization As A Unifying } \\
\text { Concept Of Differences }\end{array}$ & $\begin{array}{l}\text { Market (4), Family (3), Village (2), Teapot (2), Metropol (1), 21 } \\
\text { Communication (1), District (1), Industry (1), Supermarket (1), Picture } \\
\text { (1), Soccer Ball (1), Military (1), Neighborhood (1), Matryoshka (1) }\end{array}$ \\
Globalization As A Concept To \\
$\begin{array}{l}\text { Enhance Communication And } \\
\text { Interaction }\end{array}$ & $\begin{array}{l}\text { Shopping (3), Technology (2), Village (2), İnternet (2), Time Travelling (1), 19 } \\
\text { Whirlpool (1), Human (Live) (1), Knowledge Society (1), Butterfly Effect } \\
\text { Globalization As A Harmful } \\
\text { Concept }\end{array}$ & $\begin{array}{l}\text { Whirlpool (2),Desert (1), Competition (1), Peer Bullying (1), Bee (1), 13 } \\
\text { Swamp (1), Pit (1), Smoking (1), Damaged Scales (1), Degeneration (1), }\end{array}$ \\
Globalization As An & Blaze (1), Fire (1) & \\
Indeterminate Concept & Fog Screen (1), Book With No Page Number (1), Heterogeneous Fluid (1) & 3 \\
Total & & \\
\hline
\end{tabular}


Some of the participants' opinions regarding the categories shown in Table 2 are as follows:

\section{a) Globalization as a concept to unify differences}

21 metaphors were produced in this category. Teachers perceive globalization as a concept that brings together the differences, in doing so, that in fact, standardizates many things. The views of participant for this category given as follows:

"Globalization is like a market; because the different colors of the world coexist"(Teacher 29).

"Globalization is like a family; because it requires integration" (Teacher 42).

"Globalization is like a supermarket; because it contains many different concepts" (Teacher 31).

"Globalization is like a military; because it will make people be monotype by destroying the differences" (Teacher 51).

\section{b) Globalization as a concept to enhance communication and interaction}

19 metaphors were produced in this category. Teachers perceive globalization as an element that enhances communication and interaction among people. Some of the participants's views on this category given as follows:

"Globalization is like shopping; because different ideas are taken and given among people by means of globalization" (Teacher 9).

"Globalization is like village; because the prevalence of the means of communication transformed the world into a small village" (Teacher 12).

"Globalization is like kinship; because it increased interaction of people in the world between each other"(Teacher26).

\section{c) Globalization as a damaging concept}

13 metaphors were produced in this category. Teachers think that globalization has corrupted the specific structures of societies, and degenerated local culture by creating a universal structure. Teachers, therefore, perceive globalization as a damaging concept. Some of the participants's views on this category given as follows:

"Globalization is like a desert; because, it will gradually dry up everything” (Teacher 1).

"Globalization is like a peer bullying; Because, Strong people always dominate on weak people, and exploit them" (Teacher 21).

"Globalization is like a swamp; because it draws everything into it" (Teacher 32).

\section{d) Globalization as an indeterminate concept}

3 metaphors were produced in this category. Teachers perceive globalization as an entirely unknown concept. Some of the participants's views on this category given as follows:

"Globalization is like a fog curtain; because it blurs the minds of the people" (Teacher 13).

"The globalization is like a book whose page numbers are unidentified; because as we examine and investigate the topic, globalization deepens. Even if it is made into a book, the topics grow and the book becomes thicker. It will have an infinite page number" (Teacher 39).

"Globalization is like a heterogeneous liquid; because it contains many complex structures" (Teacher 47).

\subsection{Findings Belonging to Views of Teachers on the Concept of Globalization}

Views of teachers on the concept of globalization were examined and the findings were examined under two categories as "effects of globalization on educational process "and "recommendations for better education in a globalized society". Findings related to these categories are given below.

3.3.1 Effects of Globalization on Educational Process

The views of teachers related to the effects of globalization on the educational process are given in table 3 . 
Table 3. Views of Teachers Related to Effects of Globalization on Educational Process.

\begin{tabular}{lll}
\hline Theme & Code & f \\
\hline Effect of globalization on education & Easy access to information through technology & 11 \\
& Information pollution & 8 \\
& Weakness in human relations & 6 \\
& Pushing to laziness & 5 \\
& Equality in opportunity & 3 \\
\hline
\end{tabular}

Views of teachers related to the effects of globalization on the educational process are grouped in the way that easy access to information through technology, information pollution, weakness in human relations, pushing to laziness and equality in opportunity.

\section{a) Easy access to information through technology}

The vast majority of teachers (11/12) stated that effect of globalization on education is to provide easy access to information through technology. Some of the participant's views on this code are as follows:

"... the desired information is more easily reached. This situation is positive for the self-development of teacher. However, while the ease of access to information provides a very large resource for teachers, students are more interested in social media, games and other things. In this sense, technology and technological tools are seen as a fashion. It is clear that our students need for guidance in this sense. "

"... at any moment, in the classroom, every piece of information can be reached in a short time. The use of resources such as encyclopedias disappeared. Unlimited resources increase the choices of students. "

"... globalization enables to use new information and access educational technologies every day in the educational process. I am convinced that young people and students who make useful programs in their school, around their home country will become a globalizing world person in the event that they closely follow the changes made in other countries."

\section{b) Information pollution}

More than half of the teachers (8/12) seem to have stated that effect of globalization on education is information pollution, as well as providing easy access to information through technology. Some of the participants' views about this code was presented exactly in the same way as in follows:

"... the side that positively influences classroom environment of the globalization is that the students can reach to the topics that they need immediately, and the side that negatively influences is that they waste lots of their time for unnecessary information and they do not spend their time for the topics they have to learn"

"... the access of children to adverse web sites in the educational process is affecting them negatively. That every information which is published on the internet is not true, is a reality"

"... In order to be targeted to reach the right information as soon as possible, unauthenticated information is in demand. This makes negative examples be normalize"

\section{c) Weakness in human relations}

Half of the teachers (6/12) seem to have stated that effect of globalization on education is weakness in human relations. Some of the participants's views about this code was presented exactly in the same way as in follows:

"Besides technology has positively effects on our lives it has also negatively effects. People can not work and fulfill their responsibilities in the family environment, on the streets and in the workplace. Keeping up the sharing platforms and communication groups prevent people from making use of their time well"

"Rapid access to social network sites on the internet can turn them into young people who passivate themselves in their inner world.

"The use of tablets and smartphones makes students dependent on social media as well as reaching to information.

"Fast consumption, excessive increase in expectations, disappointment resulting from this and alienation affect negatively."

\section{d) Pushing to laziness}


Approximately half of the teachers (5/12) seem to have stated that the effect of globalization on education is that it pushes the students to be lazy. Some of the participants' views about this code was presented exactly in the same way as in follows:

"Easy access to information is pushing them to laziness. It causes them to waste their time with unnecessary information."

"Easy access to information leads them to bring their homeworks directly as output without making analyze. This is reducing the study time of students. It may encourage easiness. "

"Since it facilitates to access to information rather than researching the topic it is pushing students to laziness. In addition, a wide variety of information is accesible for everyone. "

\section{e) Equality in opportunity}

Three of the teachers (3/12) seem to have stated that $t$ effect of globalization on education is to providing equality in opportunity among students. Some of the participants' views about this code was presented exactly in the same way as in follows.

"It provides equality in opportunity by facilitating students to access to information easily."

"Educational opportunities are increasing. The borders in education are being removed. In addition, because of the fact that the students need to have basic skills they must have a standard level of education. "

"It provides to access to desired information in a short period of time. At the same time, it advantageous for society because it provides equal opportunities for people from all walks of life. "

\subsubsection{Recommendations for Better Education in a Globalized Society}

The views of teachers related to their recommendations for a better education in a globalized society are given in table 4.

Table 4. The Views of Teachers Related to Their Recommendations for a Better Education in a Globalized Society

\begin{tabular}{lll}
\hline Theme & Code & f \\
\hline Recommendations for better education & Becoming conscious about the right information & 9 \\
in a globalized society & & 7 \\
& Openness to developments & 4 \\
& Education on technology & 2 \\
\hline
\end{tabular}

The views of teachers related to their recommendations for a better education in a globalized society are grouped in the way that becoming conscious about the right information, education on technology, openness to development and protection of national culture.

\section{a) Becoming conscious about the right information}

It was seen that more than half of the teachers (9/12) were suggesting that students should be directed to the right information for better education in a globalized society. Some of the participants' views about this code was presented exactly in the same way as in follows.

"Education in which students use the technology correctly and identify the right information on the internet should be given"

"It should be ensured that students use the Internet consciously. Attention should be paid to media literacy. In doing so, it should be ensured that they should be able to do research with the computer. "

"Students should be encouraged to investigate. They should test the accuracy of the information and take precautions to prevent this information pollution. It means that comparing information obtained from various sources and reaching the right one. Books are indispensable sources providing us always to reach more reliable information. "

"It is needed to teach the students how to access the information. In the globalizing world, it is necessary to make them to notice that every information on the virtual world is not correct. They have to be selective in this regard. "

\section{b) Education on technology}


It was seen that more than half of the teachers (7/12) suggested that necessity of educating in technology for a better education in the globalizing society. Some of the participants' views about this code was presented exactly in the same way as in follows:

"We must be a teacher who adapts to technology and development. Practices such as distance education, e-seminars and e-books are helping people become more competent by paving the way of career plans. "

"I believe that it is necessary to teach the child how to use the means of informatics. The child may not know how to get the information."

"In order to gain the skills of the 21st century students should be educated in computer science education and communication skills. Technology should be brought into close with education by project and homework presentations."

\section{c) Openness to developments}

It was seen that 4 of the teachers (4/12) suggested to be open to development for a better education in the globalizing society. Some of the participants' views about this code was presented exactly in the same way as in follows:

"I think it is more important to be able to make the child aware of what he / she can do and make them have an open and progressive perspective to innovations, and then this child who has awareness can provide development by internet and use it beneficially."

"A student-centered education should be targeted, and it should be open to innovations. Innovations need to be followed continuously. Students are very good at this issue and they need to be guided well."

"We must strive to be productive at all times by following innovations and developments in the field of new scientific and technological developments in order to move ahead ourselves further."

\section{d) Protection of national culture}

It was seen that 2 of the teachers $(2 / 12)$ suggested the protection of national culture for better education in the globalizing society. Some of the participants' views about this code was presented exactly in the same way as in follows:

"Our education policy should not be confined to the school walls. We can use our national culture and values for conveying to new generations. What is happening in the world of science can be ensured to be followed by children."

"The national culture should be protected against to erosion and assimilation over time. Because we are gaining momentum in becoming a disidentified society. "

\section{Discussion}

The aim of this research is to examine the views of teachers on the concept of globalization and their metaphorical perceptions about this concept. In accordance with this purpose, the metaphors that are related to the concept of globalization were collected from teachers in order to determine their metaphorical perceptions about the concept of globalization. In addition, face-to-face interviews were conducted with teachers through semi-structured interview form in order to determine the views of teachers on globalization and effects of globalization on education.

When the metaphorical perceptions of teachers on the concept of globalization are examined as result of analysis done, it is seen that a great majority of teachers perceive the globalization as a concept to unify differences. Indeed, metaphors such as the market, family and village that they produce can be given as an example. Teachers who use metaphors such as shopping and technology also perceive globalization as a concept that increase communication and interaction. However, some teachers preferred to explain the globalization with metaphors such as desert, swamp, pit and fog which define it as a damaging and indefinite concept. According to result of the researh conducted by Eskici \& Çayak (2018) teachers perceive concept of multiculturalism as rainbow, ashure, mosaic, rug, greenery, spice, garden, crayons, treasure, cake, music, forest, salad, table and meal. The fact that teachers relate multiculturalism to the concepts of diversity overlaps with the findings of this research. A large part of the teachers who participated in the research through these findings perceived globalization as a positive concept, but the number of teachers with negative perceptions is also undeniable. As a matter of fact, Doğan (2002) reports that the perception and adoption of globalization in education are among the current educational problems. Therefore, the positive and negative effects of the globalization process have become a subject of constant debate as much as what is the globalization process (Balay, 2004). The Kurul and Tural (2004) report that globalization is a concept that can be perceived in different dimensions, and that there are both positive and negative views on this issue. Pekiyi (2011), in his research on perceptions of school 
administrators about globalization, found that school administrators perceive globalization in a skeptical point of view, that $61.8 \%$ of school administrators participating in the survey perceive globalization as a process affecting many aspects of life negatively. In addition, $76.3 \%$ of the school administrators participating in the research consider that turning of the world into a small village as a result of globalization is an opportunity in many directions. Therefore, in this research as well, that the teachers explained the concept of globalization in different contexts using both positive and negative metaphorical imagery, shows similarity with the current information in literature.

The findings obtained as result of the content analysis of the interviews made with teachers about globalization and effects of globalization on education were examined under two categories as a name of effects of globalization on education and recommendations for education in a globalizing society. While views of teachers for effects of globalization on education are easy access to information through technology, information pollution, weakness in human relations, pushing to laziness and equality in opportunity, their views for education in globalizing societies are becoming conscious about the right information, openness to developments, education on technology and protection of national culture.

It is seen that teachers often associate their views on globalization with easy access to information through technology. The information pollution and the weakness in human relations depending on accessing information through the Internet, was associated with the concept of globalization by teachers. From this point of view, it can be concluded that teachers can not fully understand the concept of globalization. It was noticed that a large proportion of teachers associate the concept of globalization with technology. Whereas, technology is only one of the elements that taken part in globalization concept. It was assessed that the concept of globalization could not fully understood and the effects on education could not be interpreted by teachers. Moreover, it is understood that some of the teachers who associate globalization with technology perceive the use the technology as a negative condition that the student can refer wrong information or lead student to easiness.

As another result of the research, it can be considered that teachers perceive education as not learning to learn but as learning to knowledge, and that they perceive purpose of education as learning to exact knowledge. Although Turkey has been adopting a constructivist approach in education since 2005, it is seen that they still have a traditional knowledge-oriented understanding. This situation is of great importance to show that teachers are resistant to changing their educational attitudes.

As a postmodern dimension of change, there is a close relationship between the globalization that affects people, societies and states (Doğan, 2002) and the education that has a significant role in shaping society (Çelik \& Gömleksiz, 2000). Many people define globalization in the context of technology (Hytten \& Bettez, 2008). Education is seen as a process that provides continuously learning, knowing knowledge, being knowledgeable, producing knowledge, living with knowledge, in the process of globalization (Dağl1, 2007). With the influence of globalization, it is seen that the foreground of the concept of information society on the world and the information and developing knowledge and technologies have an important influence on education (Balay, 2004, Çalık \& Sezgin, 2005, Gömleksiz \& Kılınç, 2012). Hence, thanks to the developing information technologies, people can access information easily. As a matter of fact, Gürbüz (2015) reached to conclusion in his research that, $59 \%$ of the prospective teachers achieved a better education in a globalizing world. On the other hand, as Çalık and Sezgin (2005) point out, it has become important to teach the individuals how to get necessary information rather than relaying information directly to them.

Additionally, individuals need to be directed correctly about this issue in order to be able to access the exact information without drowning in information pollution. In addition to all this, even though, it increases the equality in opportunity between individuals at the point of being able to acquire information easy access to information can be regarded as a negative situation because, it may cause individuals to easiness, or make them get wrong and suspicious information without reaching real sources and doing research (Balkar \& Özgan, 2010). Therefore, this situation which was clearly indicated by the teachers participating in the research shows that expectations from the elements of the education period changed together with the globalization process. It can be said that the ideas of teachers who were research participants associating globalization with the easy access to information overlaps with the studies in the literature associating globalization with information society. In addition to these, the idea that the teachers perceive globalization as a concept empowering communication and interaction metaphorically is compatible with the idea of easy access to information that they state in the interview process. The view of teachers regarding idea that globalization supports equality in opportunity in education overlaps with statement regarding idea of Levitt (1984) that individuals at every socio economic level catch the possibility of modern education with globalization.

On the other hand, globalization does not only mean the circulation of money and goods. Globalization means that the disappearance of the old meaning of time and space concepts, the borders are not as clear as used to be and the increase 
in mutual relations of the societies (Bozkurt, 2000). However, as mutual relations increase, this situation comes to a point of relationship based on self-interest, and from this point of view, it can be considered that globalization actually weakens human relations as indicated in the teachers participating in the research. Indeed, as Ilhan (2009) points out; together with today's contemporary globalization perception, contrary to what is said, the sovereign values cause to deepening of problems, especially in underdeveloped countries rather than bringing more prosperity and happiness, and it has enlarged the gap between classes within each country. In this context, protection of national cultures in each community can be considered as an important issue in the globalization process stated by teachers. Because, indicating that cultural identity tends to be massification in globalization; Akdemir (2004) states that ideal emotions are replaced by actual phenomenons and means in this tendency, and emphasizes that the individuals have gone from social values, political and cultural participation to alienation phenomenon and head to delight, consumption and entertainment prepared by various power centers.

\section{Conclusions}

Globalization's effects are big at significant all over the world. These are also manifest in the education sector. Therefore it can be said that teachers role important in this area.

The following conclusions have been reached in this study. The opinions of the teachers can be summarized as teachers associate globalization with technology, especially with the internet. In general teachers mentioned that the effects of globalization in education are positive. Further teachers' metaphorical perceptions about globalization summarized as follows; village (4), market (4), whirlpool (3), family (3), shopping (3), teapot (2), neighborhood (2), technology (2). Withal teachers' reasons for analogy of the metaphors about globalization are grouped as; globalization as a unifying of differences concept $(\mathrm{f}=21)$, globalization as a communication and interaction enhancer concept $(\mathrm{f}=19)$, globalization as a damaging concept $(\mathrm{f}=13)$ and globalization as an indefinite concept $(\mathrm{f}=3)$.

\section{Recommendations}

\subsection{Recommendations for Practitioners}

School books should be organized in the light of globalization.

Globalization should be taught to pre-service and in-service teachers

\subsection{Recommendations for Researchers}

A scale to determine teachers' opinion about globalization should be developed.

Teachers' views on globalization Should be examined according to other variables

\section{References}

Akçay, R. C. (2003). Küreselleşme, eğitimsel yoksunluk ve yetişkin eğitimi. National Education Journal, 159, 33-49.

Akdemir, A. M. (2004). Küreselleşme ve kültürel kimlik sorunu. Atatürk University Journal of Graduate School of Social Sciences, 3(1).

Ateş, D. (2007). Political Legitimacy of Nation State: Reflections of Globalization. The International Journal Of Economic And Social Research, 3(2), 32-55.

Balay, R. (2004). Globalization, information society and education. Ankara University, Journal of Faculty of Educational Sciences, 37(2), 61-82. http://dx.doi.org/10.1501/Egifak_0000000097

Balkar, B., \& Özgan, H. (2010). Teachers' Opinions on the Effects of Globalization on the Education Process in Primary Education. Mehmet Akif Ersoy University, Journal of Education Faculty, 10(19), 1-22.

Bozkurt, V. (2000). Küreselleşmenin insani yüzü. İstanbul: Alfa Press.

Craig, G. (2003). Globalization, migration and social development. Journal of Social Development in Africa, 18(2), 49-76. http://dx.doi.org/10.4314/jsda.v18i2.23826

Çalık, T., \& Sezgin, F. (2005). Globalization, information society, and education. Gazi University Kastamonu Education Journal, 13(1), 55-66.

Çavuşoğlu, D. (2007). Küresel rekabet ortamında örgütlerde yaratıcllı kültürü ve yaratıcılık yönetimine ilişkin tutumların değerlendirilmesi (okullarda araştırma), (Unpublished master's thesis). Marmara University, 
İstanbul, Turkey.

Çelik, V., \& Gömleksiz, M. N. (2000). A critical examination of globalization and its effects on education. Firat University, Journal of Social Sciences, 10(2), 133-144.

Çınar, İ. (2009). Globalization, education and future. Journal of Theoretical Educational Science, 2(1), 14-30.

Dağl1, A. (2007). Globalization towards Turkish Education System. Dicle University, Journal of Ziya Gökalp Faculty of Education, 9(1), 1-13.

Doğan, E. (2002). Eğitimde küreselleşme. Eğitim Araştırmaları, 6, 87-98.

Elçin, E. $\quad$ B. (2012). Küreselleşmenin tarihçesi. Retrieved from http://docplayer.biz.tr/746102-Kuresellesmenin-tarihcesi-a-bora-elcin.html

Eskici, M., \& Çayak, S. (2018). Teachers' Personal Characteristics and Metaphorical Perceptions to Multicultural Education. Journal of Education and Training Studies. 6(3a), 98-108. http://dx.doi.org/10.11114/jets.v6i3a.3163.

Erdinç, Z. (1999). Küreselleşmenin istihdama etkileri. Dumlupınar University Journal of Social Sciences, 3, 111-120.

Ertuna, Ö. (2006). The new world order: Globalization. The Journal of Accounting and Finance, 30.

Ferguson, Y. H., \& Mansbach, R. W. (2012). Globalization The Return of Borders to a Borderless World. New York: Routledge.

Gömleksiz, M. N., \& Kılınç, H. H. (2012). Views of academicians on the effect of globalization on curruculum: A qualıtatıve study. Mustafa Kemal University Journal of Social Sciences Institute, 9(17).

Gürbüz, Z. (2015). The opinions of teacher candidates of social sciences on globalization (Unpublished master's thesis). Marmara University, İstanbul, Turkey.

Holton, R. (2000). Globalization's Cultural Consequences, Dimensions of Globalization. Annals of the American Academy of Political and Social Science, 570, 140-152. https://doi.org/10.1177\%2F000271620057000111

Hytten, K., \& Bettez, S. C. (2008). Teaching globalization issues to education students: what's the point?. Equity \& Excellence in Education, 41(2), 168-181. https://doi.org/10.1080/10665680801957295

İlhan, H.İ. (2009). Reflections on globalization education, (Unpublished master's thesis). Gaziantep University, Gaziantep, Turkey.

Kan, Ç. (2009). Changing values and global citizenship education. Kastamonu University, Kastamonu Education Journal, 17(3), 895-904.

Karaman, K. (2010). Globalization and education. Zeitschrift für die Welt der Türken/Journal of World of Turks, 2(3), 131-144.

Kartal, Z. (2007). The historical and conceptual dimensions of globalization. Eskişsehir Osmangazi University, Journal of Social Sciences, 8(2), 261-262.

Kaya, M. (2009). Approaches to globalization. Dicle University, Journal of Ziya Gökalp Faculty of Education, 13, 1-16.

Kılavuz, U. M. (2002). Religion in the globalized world. Uludağ University, The Review of The Faculty of Theology, 11(2).

Kirkwood, T. F. (2001). Our global age requires global education: Clarifying definitional ambiguities. Social Studies, 92(1), 10-15. https://doi.org/10.1080/00377990109603969

Kurul Tural, N. (2004). Küreselleşme ve Üniversiteler (1th ed.). Ankara: Kök Press.

Kürkçü, D. D. (2013). Küreselleşme kavramı ve küreselleşmeye yönelik yaklaşımlar. The Turkish Online Journal of Design Art and Communication, 3(2), 1-11. http://dx.doi.org/10.7456/10302100/001

Levitt, T. (1984). The globalisation of markets. The Mckinsey Quarterly, 3, 2-20. http://dx.doi.org/10.1002/tie.5060250311

Miles M.B., \& Huberman M.A. (1994). An Expanded SourceBook Qualitative Data Analysis. London: Sage.

Oliver-Hoyo, M., \& Allen, D. (2006). The use of triangulation methods in qualitative educational research. Journal of College Science Teaching, 35(4), 42. 
Oran, B. (2000). Küreselleşme ve Azınlıklar (3th ed.). Ankara: İmaj Press.

Öz-Kılınç, M. (2009). The effects of globalization process on the education and teacher's identity. (Unpublished doctorate dissertation). Ege University, İzmir, Turkey.

Pekiyi, A. (2011). Globalism perceptions of public primary school administrators. Yayınlanmamış yüksek lisans tezi. (Unpublished master's thesis). Marmara University, Istanbul, Turkey.

Pike, G. (2000). Global education and national identity: In pursuit of meaning. Theory into Practice, 39(2), 64-73. https://doi.org/10.1207/s15430421tip3902_2

Power, N. C. (2000). Global Trends in Education. International Education Journal, 3, 1-6 .

Şahin, İ. F. (2011). Küreselleşme Avrupa Birliği ve Türkiye. Ankara: Pegem Press.

Şener, B. (2014). Notions of nation state and sovereignty in globalization process. Journal of History School, 7(18), 51-77. https://doi.org/10.14225/Joh500

Titrek, O., Zafer Güneş, D., \& Sezen, G. (2013). Yükseköğretim ve Yaşam Boyu Öğrenme: Bir Model Önerisi. ICQH 2013, 12-14 Aralık 2013, Sakarya Üniversitesi Kongre ve Kültür Merkezi.

Titrek, O., Zafer Güneş, D., \& Sezen, G. (2013). Higher Education and Lifelong Learning: A Model Suggestion. ICQH 2013, 12-14 December 2013 , SAU Congress Centre.

Yalçınkaya, M. H., Çılbant, C., \& Yalçınkaya, N. (2012). The nation-state concept reshaped by the global crisis. International Journal of Economics and Administrative Studies, 4(8).

Yeasmin, S., \& Rahman, K. F. (2012). Triangulation'research method as the tool of social science research. Bup Journal, 1(1), 154-163.

Yıldırım, A., \& Şimşek, H. (2013). Sosyal bilimlerde nitel araştırma yöntemleri (8th ed.). Ankara: Seçkin Press.

Yılmaz A. (2004). İkinci küreselleşme dalgası kavram süreç ve sorunlar (1th ed.). Ankara: Vadi Press

Yılmaz, K., \& Horzum, M. B. (2005). Globalization, information technologies and unıversity. İnönü University, Journal of The Faculty of Education, 6(10), 103-121.

Yorgun, S. (1998). Küreselleşme Sürecinde Sendikalar. MESS Mercek, 12. 